\title{
Language and Power Discourse in Zulfikar Ghose's Poetry Through Lyotard's Deconstruction of Metanarratives
}

\author{
Ayesha Ashraf ${ }^{1}$, Sikandar Ali $^{1} \&$ Sundes Bashir ${ }^{1}$ \\ ${ }^{1}$ Department of English Language and Literature, University of Lahore, Pakistan \\ Correspondence: Ayesha Ashraf, Department of English Language and Literature, University of Lahore, \\ Pakistan. E-mail: awan.ayesha@rocketmail.com
}

Received: March 30, 2020

Accepted: May 9, $2020 \quad$ Online Published: May 27, 2020

doi:10.5539/ijel.v10n4p124

URL: https://doi.org/10.5539/ijel.v10n4p124

\begin{abstract}
This paper endeavors to analyze Zulfikar Ghose's selected poems All in a Lifetime and Silent Birds in light of Jean Francois Lyotard's theory of Postmodernism that was proposed in 1979. Ghose is a globally recognized Pakistani English poet and his poetry is enriched with pathos, sorrows and resistance against destruction caused due to the domination of modern metanarratives, such as progress, nationalism or political objectives. The current study also applies Foucault's theoretical concept of bio power through discourse who coined this term in his The Will to Knowledge in 1988. This study highlights the chaos, fear and anxiety of the current age that is manifested in the poems, moreover, it shows the uncertainty caused by modern scientific warfare it is no more certain when and where one is going to die. The selected poems expose the relation between discourse and power, authority, domination and hegemony. The present study also demonstrates the significant role of Pakistani literature in general that attempts to resist the violence regardless of any differences. The research ends with recommendations and suggestions for further study.
\end{abstract}

Keywords: Pakistani literature, postmodernism, metanarratives, power, discourse

\section{Introduction}

During the modern age, various discoveries in the field of science gave human kind a hope for a better life as the new inventions provided the advanced medical treatments, advanced transport system, technology and a luxurious life. Unfortunately, contrary to the progressive claims of science, history shows a different outcome in the form of numberless killings massacres and with innocent and powerless nations. In fact, the history is loaded with number of events that did not only affect the world politics, but literature, art, music and society were also influenced by this destruction. It was affected by certain disastrous events such as World War One and World War Two, Pearl Harbor, Spanish Civil War, World Trade Center attack in 2001, Hiroshima and Nagasaki atomic bombing, War on Terror, violence in Kashmir, Korea, and conflicts in Iraq and Viet Nam etc. Similarly, the ongoing conflicts in Pakistan, India, Afghanistan, Iran, and Kashmir have resulted in a massive bloodshed for last few decades. These national clashes have given rise to the phenomenon of terrorism that has engulfed the peace of the world. Moreover, it also reflects towards the lack of tolerance on the part of governments in the form of improper policies that, at times, have given way to more violence. There are different theorists and scholars who have proposed their ideas against these manmade discourses that were used to justify the selfish motives. This group of scholars included Michel Foucault, a French theorist, a renowned philosopher and a historian, who influenced various social, political and humanistic fields. His famous works are The History of Sexuality (1978) and Discipline and Punish (1991), and he is famous for his concept of power and discourse.

Like Foucault, Jean Francois Lyotard (1924-1988) was a French theorist who labeled these dominating discourses as metanarratives. His interest was interdisciplinary that included epistemology, the human mind, postmodern art, critical theory, film, time, the sublime, and a strong link between literature and politics. He authored 26 books as well as many research articles and his best known is The Postmodern Condition: A Report on Knowledge that was published in 1979. In his opinion, this current post World War two reflects a postmodern condition where the truth claims of progress, war, justice and freedom are replaced by certain micronarratives. Similarly, these destructive events have provoked the world writers, poets and literary persons to raise their voice against these acts of sheer injustice happening around the world. In fact, literature too makes an effort to narrate and analyze the traumatic history through depiction of alienation, isolation, fear, anxiety, psychological 
fears, post-traumatic stress disorder and dissatisfaction. In this way, it imparts a lesson that conflicts, wars, and massacres cannot solve the problems, rather they increase them.

The representation of trauma makes literature postmodern which has evolved as an extension or a reaction of modernism. Like English fiction, Pakistani Urdu literature too raises voice against these grand narratives and it challenges the religious, political, social, cultural and economic manipulation. It rejects the idea of wiping off the nations in the name of progressive modernization. Similarly, in English, Zulfikar Ghose's poetry generates various mini-narratives against these mentioned metanarratives of nationalism, progress and democracy. Ghose is a renowned Pakistani poet, essayist and novelist, who was born in 1935. He writes both prose and poetry, and his famous work includes The Violent West and A Memory of Asia. He has written five books on literary criticism, short stories and few novels. In 1959 he served as a journalist in London. Currently, he lives in U.S where he is a professor in the University of Texas, Austin. The current study aims to explore literary as well as an emotional response of Ghose, through his two poems, towards world disastrous historical events.

\subsection{Research Objectives}

This study attempts to achieve the following objectives:

1) To analyze the discourse as political, economic and social manifestation of power in a justified manner in the selected poems.

2) To trace the challenge that is posed by the selected poems against the metanarratives of war, progress, justice and equality regarding the selected poems.

\subsection{Research Questions}

Based on the research objectives, this study seeks to answer the following questions:

1) How do the selected poems manifest discourse as a strategy to gain power through certain metanarratives?

2) How does Ghose deconstruct and challenge the metanarratives of war, progress, justice and equality with reference to his selected poems?

\subsection{Significance of the Study}

The representation of resistance in Pakistani English poetry in the backdrop of postmodern theory is unique. This research significantly explores the role of discourse in power construction as well as its deconstruction. It also manifests the strong role played by literature in order to resist the hegemonic discourse as it attempts to condemn the domination of certain discursive notions at the cost of multiplicity of truths in postmodern condition.

\section{Literature Review}

Postmodern literature exposes the epistemological ruptures existing in the narratives of enlightenment, freedom and liberty. It is, in fact, a reaction to modern weapons and scientific technologies that have always been used in the name of progress to wage various world wars. According to Brian McHale (2003), there are various constructions of postmodernism as he states:

Thus, there is John Barth's postmodernism, the literature of replenishment; Charles Newman's postmodernism, the literature of an inflationary economy; Jean-François Lyotard's postmodernism, a general condition of knowledge in the contemporary informational regime; Ihab Hassan's postmodernism, a stage on the road to the spiritual unification of humankind; and so on. There is even Kermode's construction of postmodernism, which in effect constructs it right out of existence (p. 4).

McHale (1992) in his Constructing Postmodernism calls this postmodern condition as the "anxiety of metanarratives" (p. 5). The philosophical phenomenon of postmodernism is very recent though, but it is not possible to trace the exact date of its beginning. It has influenced all the major fields of life, and it has proved to be "a movement in architecture, art, popular culture and philosophy" (Kench, 2013, p. 5). Initially, the metanarrative of war was challenged due to the immense destruction caused by modern technology, chemicals, war weapons and atomic bombs. Later on, postmodern scholars and philosophers protested against technology produced violence as Heidegger (1977) in The Question Concerning Technology states, "Everything depends on our manipulating technology in the proper manner as a means" (p. 103). Similarly, David Miller and Greg Philo (2000) view postmodernism as:

We share with post-modernists, for instance, a commitment to scrutinize and deconstruct the cultural consensus; to challenge simplistic uses of universal concepts such as 'citizenship' and 'human rights' to hide differences and inequalities; to subvert modernist optimism in technological 'progress' and reveal values embedded in shaping our cultural and social life rather than simply reflecting a reality 'out there' ( $\mathrm{p}$. 
127).

This challenge, with respect to grand narrative of war and science, became visible especially after World War Two as according to Malpas (2003), "Postmodern art is usually associated with more recent writers and artists, generally those working in the aftermath of the Second World War" (p. 8). These writers exposed the brutal impact of the war, on the entire world, in the form of psychological disturbances, harmful rays, growing infertility, unemployment and strong sense of confusion. Foucault also relates power to the discourse uttered by everyone, anywhere, irrespective of his/her position, and he is of the view, that power is not concentrated. He considers discourse as a strategy to gain power that in turns formulates a strong link with the society. Foucault (1978) in The History of Sexuality argues, "I am not referring to Power with a capital P, dominating and imposing its rationality upon the totality of the social body. In fact, there are power relations. They are multiple; they have different forms, they can be in play in family relations, or within an institution, or an administration" (p. 38). He considers that power is "coextensive with resistance; productive, producing positive effects; ubiquitous, being found in every kind of relationship, as a condition of the possibility of any kind of relationship, and where there is power there is resistance" (ibid). Pakistani literature deconstructs the metanarratives and exposes the invisible propagandas that function behind the dominance of such notions.

Pakistani literature especially depicts the humiliation committed against the western Muslims in the aftermath of World Trade Center attacks. There are several novels that seem to lament at this situation that has brought the irreversible damage to the harmony between Muslims and non-Muslims, who are living in America. Masud Mufti's Pardesi and Iftikhar Naseem's Shanakht were the short stories published in the year 2002, and these are based on 9/11 conflicts. In the same way The Reluctant Fundamentalist by Mohsin Hamid (2012) is an English novel that revolves around the story of a young Pakistani, who serves in America with full devotion but is suspected for being involved in 9/11 tragedy. America invaded Iraq after 9/11 incident and did massive killings. Ahmad Nadim Qasmi (2002) in his Aishya depicts a deep sorrow against the cruel policies made by different governments. Kamila Shamsie's Burnt Shadows depicts the atrocities committed by different governments through waging wars in different continents of the world. Muneeza Shamise, a literary critic and a Pakistani writer, comments on this novel as, "Burnt Shadows takes in a grand sweep of history from the Second World War to Guantanamo Bay" (2011, p. 119).

However, in English poetry, Zulfiqar Ghose has been read and researched by many scholars who have attempted to find out the resistance against the so-called metanarratives of modern science. Dr Rizwan Akhtar and Rabia Zaheer (2019) state, "Ghose has frequently been acknowledged, anthologized and appreciated along with the other established Pakistani poets of his generation like Alamgir Hashmi, Daud Kamal, and Taufiq Rafat" (p. 253). Ghose is appreciated not only for the content of his poetry but also for its innovative form and style as Fredrick Ruban (2016) states, "Zulfikar Ghose, a living Pakistani American writer, is renowned for landscape poetry as well as for magical realism writing" (p. 40). Mansoor Abbasi (2015) states, "Ghose's work is full of sociopolitical matter. But the content, as suggested earlier, is not independent of his style" (p. 9). The fact, that Ghose's poetry challenges the notions, such as nationalism and progress, has been explored by many scholars such as Fiaz, Rafique and Tabasum (2019) comment, "His few poems are about partition scenario and multicultural background of India, in them partition has been taken as a game of power" (p. 717). There are some other research studies on his poetry which cater various dimensions of his thoughtfulness, but the study from postmodern perspective was still lacking, and my study attempts to fill this gap.

\section{Research Methodology}

The current research is qualitative and exploratory in nature. Its analysis the selected two poems in order to trace the link between discourse and power. Textual analysis is used as a research method as Alan Mckee (2003) defines, "When we perform textual analysis on a text, we make an educated guess at some of the most likely interpretations that might be made of the text" (p. 1). Jean Francois Lyotard (1925-1998) theoretical concept of mini-narratives is applied to analyze the data. He believes that "modern science to be built on shaky foundations" (cited in Kench, 2013, p. 21), and he calls this hold of science as language games. Moreover, history also proved later on that this failure of science led to "the end of an objective world with its truth and justice" (ibid). This disastrous impact of science challenged all the existing grand narratives and Lyotard (1984) states, "I will use the term modern to designate any science that legitimates itself with reference to a metadiscourse of this kind making an explicit appeal to some grand narrative such as the dialects of Spirit, the hermeneutics of meaning, the emancipation of the rational or working subject, or the creation of wealth" (p. 23).

According to Lyotard's philosophy of postmodernism, there are various mini-narratives or language games that replace the grand narratives, and, in this way, they transform modern claim of emancipation. Maroof (2012) 
writes in his research article Is Religion a Metanarrative?: Towards Religious Critique and Appropriation of Postmodernism, "Lyotard introduced the term grand narrative in his The Postmodern Condition to describe the kind of story that underlies, gives legitimacy and explains the particular choices a culture prescribes as possible courses of action" (p. 24). Similarly, Malpas (2003) analyses this centralization of the knowledge from the postmodern perspective as he states, "According to Lyotard, the status of knowledge is altered as our societies enter what is known as the postindustrial age and cultures enter what is known as the postmodern age" (p. 3).

On the other hand, Foucault's idea of using language as a strategy to gain power is crucial for my study as it explores the discourse as positive and negative form of domination. Foucault is of the opinion that power is related to individuals and political system, moreover, any state formulates hegemonic discourse to run the government. He in his Discipline and Punish: The Birth of the Prison traces the history of political power when he argues, "Power produces; it produces reality; it produces domains of objects and rituals of truth" (1995, p. 194). He deconstructs the idea of government as who will rule and who should be ruled? What should be the strategies to rule? He views the relationships between parents and children, teachers and students, between employers and employees, and between lovers based on power dynamics.

The discussed theoretical points proposed by Lyotard and Foucault are related to the poems under investigation in terms of challenge that they pose to various grand narratives.

\section{Analysis and Discussion}

The selected poems express a profound sense of grief over the brutality of war, or any war, that leads to the generation of further local and global conflicts. The poems employ postmodern characteristics in order to challenge the existing metanarratives regarding science and enlightenment. Moreover, they also generate mini-narratives that replace these grand stories which claim for objectivity and neutrality. Postmodern chaos is thoroughly reflected in the poems and it demonstrates that nothing remains certain in the wake of wars. Metanarratives of truth, knowledge, legitimacy and identity are being challenged in the selected poems. In fact, these poems reflect Ghose's imagination which is saturated with full horror and violent war images, and the disastrous impact of various conflicts on the humanity has thoroughly captivated his mind. He does not favor any single nation, country or ideology; rather he condemns the loss of values of humanity in the name of modern progress.

\subsection{Silent Birds}

The poem Silent Birds comprises of seven stanzas, and it is about subcontinent i.e. Pakistan and India. Before the Partition 1947, these countries lived in peaceful harmony for many years despite having different religions. The Partition event separated these countries and made them rivals to each other. It also shows that, there was no great goal to pursue rather it brought only a directionless brutality. The decision was made by the specific sections of government but a lay man was kept isolated and emotionally exploited during the course of action. Silent Birds also reflects that there is no objective truth in the grand narrative of the Partition 1947, and there may be some conflicts on political level but, from a common man's perspective, Hindus and Muslims living in these divided countries are still as loving as they once used to be. The poem attempts to represent the effect of trauma with a focus on both, i.e., human beings as well as the birds. It highlights the fact, that environmental degradation in the form of bloodshed and killing does not only harms a man, but it also affects the animals. They feel the same pain of loss as it writes:

"It was the month I flew to Pakistan

The crows were quiet in Lahore, I read" (lines 1-2)

In the above lines the quietness and painful silence, of the birds, is focused by the poet in an investigating tone. Later, in the second stanza poem proceeds with the warning that birds are fearful of the environment in Bombay due to the terrorist attacks. It also refers to the prevailing terrorism in Pakistan and India, that is due to the strong rivalry between these countries. It laments at the incidents, such as bomb blasts, which instill a permanent fear in the minds of people. It states:

"Bombs suddenly exploded at the world

Performing Arts Festival in Lahore, My

Family home shook as in an earthquake

A day later news came from Bombay of

A Terrorist attack on the Taj hotel." (lines 13-17) 
Line number 15 shows the outcome of war that brings many physical and psychological pains for the human beings, and this suffering is juxtaposed with the grief of the birds. It analyzes the manmade explosions in an ironic tone that these disastrous incidents are so horrible that it seems that some natural calamity has come down to destroy the whole humanity from the face of the earth. The poem especially refers to the rivalry between Pakistan and India quite clearly in line 16-17 as 'one day later' Bombay was attacked after the terrorist attack in Pakistan. It has cast a very negative relationship between the governments of both the countries as well as their citizens, who have estranged them from one another. The poem deconstructs the metanarrative of science through depiction of huge catastrophe that it has caused; moreover, its materialistic impact has also diminished the existence of prosperous human values and tolerance in societies. Time and again, it refers to the sad fact that not only human beings but birds also feel the pain of violence and they protest against it by getting silent. The poem can be viewed in the light of Foucault's idea, who states that resistance against any hegemonic discourse is itself a form of power. He states, "Power must be analyzed as something which circulates, or as something which only functions in the form of a chain ... Power is employed and exercised through a netlike organization ... Individuals are the vehicles of power, not its points of application" $(1978$, p. 98). Similarly, the poem exposes silence as a form of resistance as following:

"Noisy at sunrise

And sunset, parakeets in a green cloud

Above the mango tree, grown silent now,

Without a voice in what to expect next". (lines 9-12)

The line number 9 reflects the postmodern chaos that can be seen in the wake of modern invention of weapons, warfare, and atomic bombs, that neither brought any peace to the humanity nor any solution to the prevailing conflicts. In fact, one technology is killing the other, i.e. one bomb attack is replied with another bomb attack or war, and these destructive means are used to control the whole world. Van Dijk (2008), being one of the pioneers of critical discourse studies, relates the discourse with power and he opposes the hegemony of discourse of grand narratives. He states, "However, as a general rule of thumb, we can speak of illegitimate use of discursive power, that is, of domination, if such discourse or its possible consequences systematically violate the human or civil rights of people" (p. 21).

The poem narrates the silence of birds, that even they feel insecurity, and they know that anything can happen at any time. The poem laments at the fact that, in today's modern age of science and warfare, a huge humanity can be diminished in just few minutes. Though, Ghose incorporates multiple and plural identities, and he favors all the humanity irrespective of any discrimination of cast, color, nation and faith. In the end of the poem, he gives a message that everyone needs to protest to this never ending ongoing loss of values which are desperately needed to be restored in order to get a peaceful society. The poem also seems to provoke the readers to re-gain basic values of humanity, and it refers to the responsibilities of various sections of the society as well in order to maintain a uniformed stance against any hegemonic discursive practice. The last stanza shows the significant role of religious scholars as being an authority they can take the lead to inculcate moral values in people. The poem states:

"Nothing at all. Absolutely nothing

The priest shrilly called the faithful

To prayer as if nothing had happened

O God" (line 39-42)

\subsection{All in a Life Time}

This poem narrates Ghose's autobiographical experience regarding world politics. It is postmodern in a true sense, as it lacks any coherence and poetic unity. It is not a traditional poem rather fragmented, because postmodern age itself is fragmented, so it propagates the view that coherent narrative pattern cannot justify the fragmented nature of reality. The very first stanza of the poem comprises of 20 lines while the second stanza consists of 9 lines. Last stanzas comprise of 5 lines each with 4 lines in the very last stanza. The poem represents that there is no 'objective' truth behind any war or even if it is fought for the progress of one nation it still may not be justified from the perspective of the other nation. Ghose starts the poem with the ironic description of wars, that it only kills massive humanity. By challenging the hegemonic discourse, the poem subverts the power itself as Foucault (1978) states, "Power is coextensive with resistance, it is productive-i.e., it causes positive effects, and it is ubiquitous - i.e., it can be found in any type of relation between the members of society, being a 
possibility condition for any relation" (p. 142). Similarly, the poem presents an ironic commentary on the grand narrative of war, that it is waged only to achieve some materialistic gains, and no progress actually exists there. It writes:

"During my lifetime there has been a World War

And several other wars killing millions;" (line 1-2)

These lines manifest that, as a postmodern poem, it merges different genres together such as history, geography, sociology, politics, science and few biographical notes. It also combines history and trauma in order to resist man made violence, as it states:

"I remember all these wars

For the remarkable fact that I escaped them all

It's like having constantly been under

A cloud but always out of rain" (line 17-20)

The above lines show postmodern anxiety that refers to current era of destruction, that is brought exclusively in the name of progress. These refer indirectly to the invention of modern fatal weapons that have caused huge destruction by killing many innocent lives. Similarly, the narrator of the poem, as a postmodern subject, is not certain what is going to happen to him in future, because up till now he has escaped the wars but he feels a constant fear. The poem also laments at the inactive life that is caused due to this fear of war, conflicts and violence. It writes:

"There have been riots at football

Stadium where the innocent have been trampled

To death, demonstrations that have turned

Into riots, thoughtless killing by mobs

and the police. And some unfortunate who'd not meant

to be there happened to be there and got shot." (line 24-29)

Like Silent Birds, Zulfiqar Ghose in All in a Lifetime again shows his concern over various ongoing political issues between Pakistan and India. In fact, he has written this poem in a declarative mode while keeping the tone serious, and he seems to be involved in a conversation with the reader. It is written in free verse style with six stanzas of different length. The poem is full of imagery of destruction, war, bloodshed, catastrophe, existentialism, and fear. The poet does not take side with any country, rather he laments on the violence that has been done to any community in the name of various grand narratives, such as freedom, nationalism, patriotism and science. He seems to be in a state of disbelief that the countries that had been living together peacefully for almost thousand years, are now at war. Just like Lyotard's philosophy, Ghose does not endorse any single fixed identity of any nation, rather he deconstructs the concept of fixed nationalities. He expresses grief at the conflicts that are generated from one sided perspectives of rulers who impose their unjust decisions on their citizens. He directly criticizes the dictators who ignore the perspective of lay men. He keeps on counting all historical destructive events that happened in different countries of the world. The poem highlights as:

"And several other wars killing millions;

I was a boy when Hitler blitzed London

And the Japanese bombed Pearl Harbor,

I came of age when France and Britain

Attacked Suez. A little later, India invaded

Pakistan; then Israel and Egypt

shared a murderous week. Then there

Have been Kashmir, Korea, Biafra and, of course,” (Line 2-9)

He criticizes all the nations and their governments, for the negative role, that they have played in creating conflicts in the entire world. He writes:

"In India, Negros and Whites in America,

general butchery on the whole planet 
from dictators." (line 21-24)

These mentioned lines attempt to lament on the ruined relationship between Hindus and Muslims of Indo-Pak subcontinent. This sorrow can be viewed with the perspective of freedom narrative that was used to divide it in 1947. Like many novelists and poets from India and Pakistan, Ghose does not agree with the freedom stance that brought so much suffering and violence. The poem further deconstructs the grand narrative of science that boasts of its advancement by depicting the catastrophe caused by man-made machines like airplanes, cars, trains and dams etc. It writes:

"Or there have been accidents. Plain Crashes,

train derailments, buses falling down ravines,

mines collapsing, bridges falling, dams bursting.

And road accidents, of course, the good old highway

of life on which you can vanish in a moment". (Line 35-39)

These lines show that human being cannot claim to be solely rational and flawless as many of the manmade inventions can cause greater harm than the good. Moreover, science is not the guarantee of prosperity, rather it is, sometimes, very much destructive in the form of wars, weapons, chemicals, poisonous acids, road accidents, bloodshed and so on. The poem ends at the line, "I don't know how I manage this" and this is a clear question posed by Ghose that further gives way to numberless questions. He provokes the reader to think about an escape or a challenge that is to be posed to the existing grand narratives which will be replaced by mini narratives. This question also exposes the underlying anxiety, depression, fear, and uncertainty that, according to Lyotard, is always experienced by a subject in the postmodern condition.

\section{Conclusion}

This study has scrutinized the two selected poems written by Zulfiqar Ghose in light of Lyotard's philosophy of negation of metanarratives in the wake of postmodern age. The study has also analyzed the relation between discourse and power in the poems through depiction of unjust wars, bloodshed and killings. It has found that these poems resist violence caused by war and especially they refer to the Partition of Indo-Pak subcontinent. Ghose attempts to make the readers realize the brutalities of war by drawing their attention towards political history and the cruel usage of modern technology. He highlights the ethical dilemma by focusing on unjust killing of innocent children, women and men. Moreover, it has traced that, from spiritual perspective, these poems give a warning message to the nations out there to stop the wars around the world in order to build a peaceful society. Like Zulfiqar Ghose, there are many other emerging poets who use language, metaphors, imagery and symbols to protest against the unjust treatment towards human beings and animals. There are some playwrights as well, for example, Usman Ali who hails from Pakistan, and he has written ten plays on different issues. This study strongly recommends Ali's work for future research in terms of its representation of various current issues in the backdrop of Lyotard's concept of the postmodern condition.

\section{References}

Abbasi, M. (2015). Zulfikar Ghose: The Lost Son of the Punjab. Cambridge Scholars Publishing.

Apologetics, C., Kench, A., \& Willoughby, R. (2013). A Critical Analysis of Jean-Francois Lyotard's 'The Postmodern Condition: A Report on Knowledge with Respect to Christian Apologetics (pp. 1-67). Masters dissertation. Retrieved from https://www.academia.edu/5566552/Dissertation

Arif, N. (2011). 9/11 and Urdu Literature: A Sociopolitical Study of Urdu Fiction and Poetry in Pakistan. The Annual of Urdu Studies, 26, 87-95.

Bibby, M. (Ed.). (1999). The Vietnam War and Postmodernity (pp. 143-171). Univ of Massachusetts Press.

Fiaz, M., Rafique, H., \& Tabasum, F. (2019). Power Discourse: Analysis of Zulfikar Ghose Collection of Poems in perspective of Michel Foucault's Bio Power Theory. International Journal of English Literature and Social Sciences (IJELS), 4(3), 711-717. https://doi.org/10.22161/ijels.4.3.24

Foucault, M. (1978). The History of Sexuality (Vol. 1). New York: Pantheon Books.

Foucault, M. (1995). Discipline and Punish: The Birth of Prison (2nd ed., Alan Sheridan trans.). New York: Vintage Book.

Heidegger, M. (1977). The Question Concerning Technology (pp. 3-35). New York: Harper \& Row.

Lyotard, J. F. (1984). The Postmodern Condition: A Report on Knowledge (Vol. 10). University of Minnesota 
Press. https://doi.org/10.2307/1772278

Malpas, S. (2003). Jean-François Lyotard. Routledge.

Marshall, B. K. (1992). Teaching the postmodern: Fiction and theory. New York and London: Routledge.

McHale, B. (1992). Constructing Postmodernism. Psychology Press.

McHale, B. (2003). Postmodernist Fiction. Routledge. https://doi.org/10.4324/9780203393321

McKee, A. (2003). Textual analysis: A Beginner's Guide. Sage. https://doi.org/10.4135/9780857020017

Philo, G., \& Miller, D. (Eds.). (2000). Market Killing: What the Free Market Does and What Social Scientists Can Do About It. Longman: Harlow.

Ruban, A. F. (2016). Reminiscence surfaces diasporic consciousness: A comparative analysis of indigenous and overseas episodes of Zulfikar Ghose's "This Landscape, These People”. International Journal of English Research, 2(6), 40-42.

Shah, M. M. (2012). Is religion a metanarrative? Towards Religious Critique and Appropriation of Postmodernism. International Journal of Humanities and Religion, 1(1), 24-34.

Shamsie, M. (2011) Duality and diversity in Pakistani English literature. Journal of Postcolonial Writing, 47(2), 119-121, https://doi.org/10.1080/17449855.2011.557178

Van Dijk, T. A. (2008). Discourse and Power. Macmillan International Higher Education. https://doi.org/10.1007/978-1-137-07299-3

Zaheer, R., \& Akhtar, R. (2019). Alien Voices and Dialogic Discourse in Zulfikar Ghose's Poetry. Journal of Research (Humanities), (55), 251-267.

\section{Copyrights}

Copyright for this article is retained by the author, with first publication rights granted to the journal.

This is an open-access article distributed under the terms and conditions of the Creative Commons Attribution license (http://creativecommons.org/licenses/by/4.0/). 